\title{
Helminth parasites of the southern sea otter Enhydra lutris nereis in central California: abundance, distribution and pathology
}

\author{
Karl A. Mayer ${ }^{1}$, Murray D. Dailey ${ }^{2, *}$, Melissa A. Miller ${ }^{3}$ \\ ${ }^{1}$ Moss Landing Marine Laboratories, 8272 Moss Landing Rd., Moss Landing, California 95039, USA \\ ${ }^{2}$ Marine Mammal Center, Marin Headlands, 1065 Ft. Cronkhite, Sausalito, California 94965, USA \\ ${ }^{3}$ Marine Wildlife Veterinary Care and Research Center, 1451 Schaffer Rd., Santa Cruz, California 95060, USA
}

\begin{abstract}
From October 1997 to May 2001, the gastrointestinal tracts from 162 beach-cast southern sea otters Enhydra lutris nereis were examined for helminth parasites and associated lesions. Carcasses were collected opportunistically in central California between Pt. San Pedro and Pt. Arguello. The primary goals of this study were to examine spatial and temporal variability in mortality due to parasite infection, identify factors associated with increased risk of infection, and illustrate the process of intestinal perforation by Profilicollis spp. Two genera and 4 species of acanthocephalans (Profilicollis altmani, P. kenti, P. major, Corynosoma enhydri) were found in $46.3 \%$ (Profilicollis spp.) and $94.4 \%$ (C. enhydri) of the carcasses examined. Three species of Digenea (Microphallus pirum, M. nicolli, Plenosoma minimum) were found in $47 \%$ of carcasses, at times in massive numbers $\left(>3000\right.$ per $\mathrm{cm}^{2}$ ). This is the first report of the latter 2 species from the sea otter. Mortality resulting from infection by Profilicollis spp. occurred in $13.0 \%(\mathrm{n}=21)$ of sampled carcasses, either directly, due to perforation of the intestinal wall and peritonitis $(9.9 \%, \mathrm{n}=16)$, or indirectly, due to inhibition of host nutrient uptake or depletion of host energy reserves to fight chronic infections $(3.1 \%, n=5)$. The most massive infections ( $<8760$ parasites), and all cases of intestinal perforation occurred in carcasses infected by $P$. altmani and/or $P$. kenti. Mortality due to infection by Profilicollis spp. occurred more frequently among juvenile and old-adult females $\left(\chi^{2}=17.479, \mathrm{df}=9, \mathrm{p}=0.045\right)$ from sand and mixed habitats in Monterey and Santa Cruz in the north of the sea otter range $\left(\chi^{2}=9.84, \mathrm{df}=4, \mathrm{p}=\right.$ 0.045). Spatial differences in sea otter mortality coincided with the relative distributions of Profilicollis altmani, $P$. kenti, and P. major, and may reflect differences in sea otter diet, or differences in intensity of infection in intermediate hosts. Mortality rate due to infection by Profilicollis spp. decreased between 1998 and 2001, though differences were not significant $\left(\chi^{2}=3.983, \mathrm{df}=3, \mathrm{p}=0.40\right)$, and may vary on multi-year cycles due to environmental factors such as density of definitive hosts (e.g. the surf scoter Melanitta perspicillata), or El Niño. Corynosoma enhydri did not cause significant damage to the intestine of the host, even when present in great numbers.
\end{abstract}

KEY WORDS: Sea otter $\cdot$ Enhydra lutris nereis $\cdot$ Mortality $\cdot$ Parasites $\cdot$ Acanthocephala $\cdot$ Intestinal perforation $\cdot$ Pathology $\cdot$ Peritonitis $\cdot$ Digenea

\section{INTRODUCTION}

The southern sea otter Enhydra lutris nereis was listed as 'threatened' in 1977 under the Endangered Species Act of 1973. Previous reports of the gastrointestinal parasites of southern sea otters have described 4 species of acanthocephalans, Profilicollis (= Polymor- phus, see Nickol et al. 1999) altmani, P. kenti, P. major, and Corynosoma enhydri (see Hennessy \& Morejohn 1977), and 1 species of digenean, Microphallus pirum (see Margolis et al. 1997).

In a recent study investigating mortality in the southern sea otter, Thomas \& Cole (1996) found that peritonitis caused by extra-intestinal migration of larval 
acanthocephalans (Profilicollis spp.) was the cause of death in $14 \%$ of sampled carcasses $(\mathrm{n}=195)$, and prevalence of this disease appeared to increase in frequency between 1992 and 1995. By comparison, Hennessy \& Morejohn (1977) found only 1 case of extraintestinal migration by $P$. kenti in a sample of 80 sea otter carcasses collected in the late-1960s/early-1970s. The relative distribution of these parasites within the southern sea otter population has not been described, nor has the pathology and host reaction associated with penetration and perforation of the intestinal wall.

Acanthocephalans have complex life cycles involving a free-living egg stage, an arthropod intermediate host, and a vertebrate definitive host (Hyman 1951). Transmission of profilicollid acanthocephalans to the sea otter occurs through ingestion of the sand crab Emerita analoga and the spiny mole crab Blepharipoda occidentalis (see Hennessy \& Morejohn 1977). The rock crab Cancer irroratus was identified as an intermediate host for Profilicollis major on the east coast of the United States (Schmidt \& MacLean 1978), but C. irroratus has not been verified as an intermediate host in California. Definitive hosts for Profilicollis spp. include gulls (Larus spp.), scoters (Melanitta spp.) and the sea duck (Clangula clangula; see Hennessy \& Morejohn 1977). Sexually mature adult stages of Profilicollis spp. have not been found in the sea otter (Thomas \& Cole 1996). An intermediate host has not been identified for Corynosoma enhydri, and the sea otter is the only known definitive host for this parasite (Hennessy \& Morejohn 1977). Unlike Profilicollis spp., C. enhydri has not been found to deleteriously affect the sea otter, even when present in great numbers (Thomas \& Cole 1996).

The goals of the present study were to (1) examine spatial and temporal variability in mean parasite density (Rohde 1982) and mortality due to infection by Profilicollis spp. on a sample of southern sea otter carcasses, and (2) identify factors associated with increased risk of infection. In addition we described spatial and temporal variability in infection by Corynosoma enhydri, illustrated the process of intestinal perforation by Profilicollis spp., and identified 2 species of Digenea not previously noted in the southern sea otter.

\section{MATERIALS AND METHODS}

Sea otter carcass collection and necropsy. Intact gastro-intestinal tracts were removed from 162 sea otter carcasses opportunistically recovered in central California (Pt. San Pedro to Pt.Arguello) between October 1997 and May 2001 (Fig. 1). This sample represents $25 \%(n=651)$ of southern sea otter carcasses recovered during that period (B. Hatfield, US Geologi- cal Survey, Biological Resources Division, pers. comm.). The condition of carcasses examined in this study ranged from freshly dead to advanced decomposition, and was determined by field biologists at the time of carcass recovery (J. Ames, California Department of Fish and Game, pers. comm.). Age category of each animal (pup, juvenile, sub-adult, adult, old-adult) was estimated based on total body length, dentition, and tooth wear. Date of carcass recovery was grouped into seasons as follows: autumn (September through November), winter (December through February), spring (March through May), and summer (June through August).

For spatial comparison, carcass recovery sites were grouped from north to south into 11 contiguous areas based on predominant habitat-type (sand, rock, or mixed sand and rock; Table 1). Habitat-type was used as the basis for spatial analysis because this factor influences distributions of crustacean intermediate hosts: Areas of rock habitat contained relatively large amounts of kelp and predominantly rocky coastline; areas of sand habitat contained large stretches of sand beach, no rocky coast, and little or no kelp; and areas of mixed habitat contained some rocky coast, occasional headlands and coves with sand beaches, and little or no kelp (Laidre et al. 2001). Recovery sites between Pt. Piños and Pt. Joe, and Pescadero Pt. and Pt. Lobos (Fig. 1) were classified as mixed instead of rock, despite having large amounts of kelp, because areas of sandy beach occur amidst rocky coastline in both areas.

Most sea otter carcasses were stored at the Marine Wildlife Veterinary Care and Research Center (MWV$\mathrm{CRC}$ ) in Santa Cruz, California prior to examination. Necropsies were performed by a pathologist or field biologist, who determined a cause of death whenever possible. The entire intestinal tract was removed during necropsy and frozen for later examination.

Parasite sampling and identification. The intestinal tract was thawed, placed on a table, separated into meter-long segments, opened, washed, and examined grossly for the presence of parasites. Acanthocephalans were relaxed in fresh water prior to fixation. Acanthocephalans and digeneans were fixed in alcohol-formalin-acetic acid (AFA) solution and stored in $70 \%$ ethanol. Staining and mounting of specimens for identification followed Dailey (1996). Species of Profilicollis were distinguished using morphologic and morphometric characteristics of the proboscis, including, number of proboscis hooks per row, number of rows, and diameter of proboscis (Amin 1992). Additional acanthocephalan and digenean parasites collected from southern sea otter carcasses by the National Wildlife Health Center in Madison, Wisconsin, were utilized for taxonomic determination, but were not included in analyses. 
Table 1. Enhydra lutris nereis. Carcass recovery areas were grouped based on habitat-type. Rocky habitat contained moderate to large amounts of kelp and moderate to large amounts of rocky substrate; sandy habitat contained no rocky coast, no kelp, and no sub-tidal rocky substrate; and mixed habitat contained some rocky coast, occasional headlands and coves, little or no kelp, and minimal sub-tidal rocky substrate (Laidre et al. 2001)

\begin{tabular}{|c|c|c|c|c|}
\hline Recovery area & & $\begin{array}{l}\text { Habitat } \\
\text { type }\end{array}$ & $\begin{array}{l}\text { Carcass } \\
\text { sample }\end{array}$ & $\begin{array}{l}\text { Distance along } 10 \mathrm{~m} \\
\text { depth contour }(\mathrm{km})\end{array}$ \\
\hline North coast & Pt. San Pedro - Pt. Ano Nuevo & Mixed & 4 & 70 \\
\hline Santa Cruz & $\begin{array}{l}\text { Pt. Ano Nuevo - Soquel Pt. } \\
\text { Soquel Pt. - Moss Landing }\end{array}$ & $\begin{array}{l}\text { Mixed } \\
\text { Sand }\end{array}$ & $\begin{array}{c}8 \\
25\end{array}$ & $\begin{array}{c}43 \\
27.5\end{array}$ \\
\hline Monterey & $\begin{array}{l}\text { Moss Landing - Monterey Municipal Wharf } \\
\text { Pt. Piños - Pt. Joe, Pescadero Pt. - Pt. Lobos } \\
\text { Monterey Municipal Wharf - Pt. Piños, } \\
\text { Pt. Joe - Pescadero Pt., Pt. Lobos - Yankee Pt. }\end{array}$ & $\begin{array}{l}\text { Sand } \\
\text { Mixed } \\
\text { Rock }\end{array}$ & $\begin{array}{l}23 \\
19 \\
23\end{array}$ & $\begin{array}{c}27.5 \\
10.5 \\
26\end{array}$ \\
\hline Central Range & Yankee Pt. - Cayucos Pier & Rock & 14 & 178 \\
\hline Morro Bay & $\begin{array}{l}\text { Cayucos Pier - Hazard Canyon } \\
\text { Hazard Canyon - Shell Beach }\end{array}$ & $\begin{array}{l}\text { Sand } \\
\text { Rock }\end{array}$ & $\begin{array}{c}25 \\
5\end{array}$ & $\begin{array}{l}18.5 \\
50.5\end{array}$ \\
\hline Pismo Beach & Shell Beach - Pt. Sal & Sand & 16 & 26.5 \\
\hline South coast & Purisima Pt. - Pt. Arguello & Sand & 2 & 20.5 \\
\hline
\end{tabular}

Histopathological examination. Sections of intestine and omentum containing acanthocephalans from selected freshly dead otters were immersion-fixed in $10 \%$ neutral buffered formalin. These tissues were dehydrated in ethanol, embedded in paraffin, sectioned at $5 \mu \mathrm{m}$ and stained with hematoxylin and eosin (H\&E). Step sections and/or $5 \mu \mathrm{m}$ serial sections were completed from some paraffin blocks of intestine containing transmural acanthocephalan parasite profiles to document anatomic details of the parasites as well as host-tissue reaction.

Statistical analyses. Two variables were considered in statistical comparisons: (1) mean abundance (the total number of parasites divided by the total number of hosts, stratified by age/sex examined, including those with no parasites, Rohde 1982), and (2) rate of mortality due to infection by Profilicollis spp. and Corynosoma enhydri were considered independently in calculating abundance of infection. Mortality due to infection by Profilicollis spp. occurred in the following cases: (1) carcasses in which intestinal perforation was observed and no other more obvious cause of death was assigned (acanthocephalan peritonitis), and (2) cases in which no intestinal perforation was observed, but abundance of Profilicollis spp. was sufficiently great as to affect nutrient uptake by the host, or cause depletion of host energy reserves to fight infection (intestinal acanthocephaladiosis). Intensity of infection was defined as the number of parasites per infected host. Prevalence was defined as the percent of host individuals infected (Rohde 1982).
A Kruskal-Wallis test (Zar 1996) was used to compare mean density of infection by Profilicollis spp. and Corynosoma enhydri among 4 factors: (1) sea otter age and sex category (pup, juvenile, sub-adult, adult, old-adult, male, female), (2) carcass recovery area

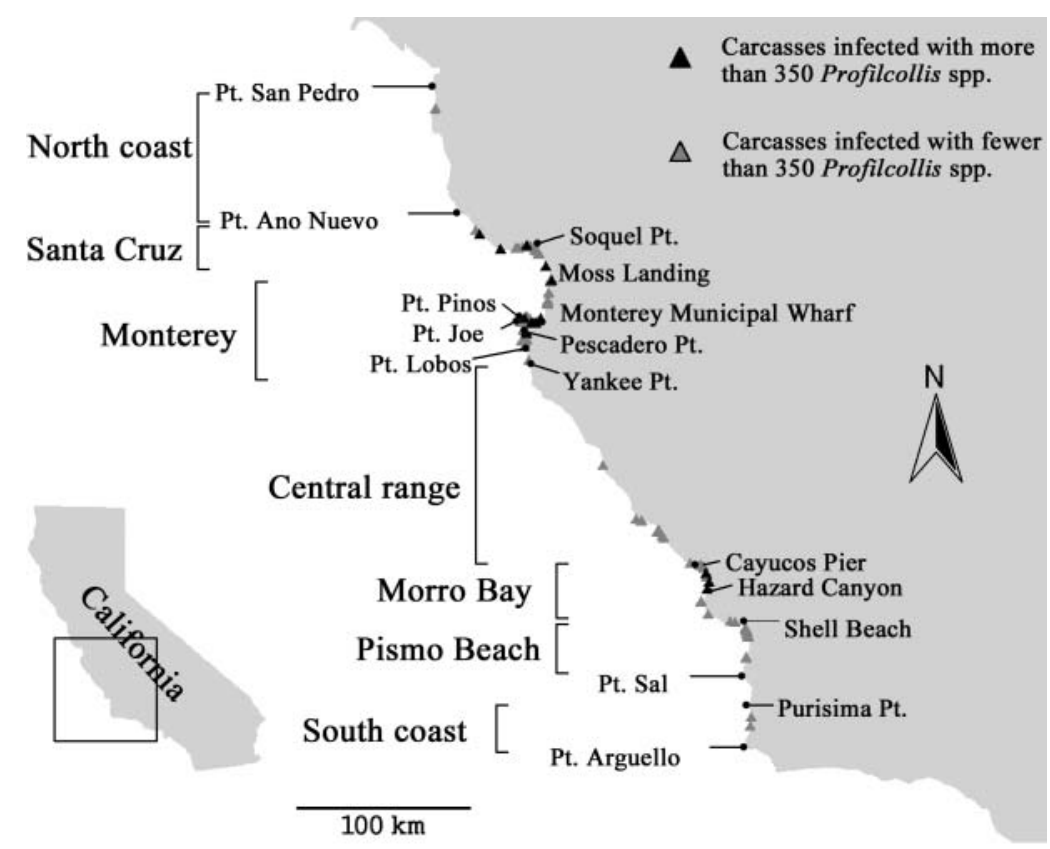

Fig. 1. Enhydra lutris nereis. Recovery locations of 162 sampled sea otter carcasses, opportunistically collected between October 1997 and May 2001 by a salvage network coordinated by the US Geologic Survey Biological Resources Division in San Simeon, CA. Carcasses with $>350$ Profilicollis spp. were considered heavily infected. Sections of coastline were grouped into broader recovery areas (indicated by brackets) based on predominant habitat type (see Table 1) 
(Table 1), (3) season of carcass recovery (autumn, winter, spring, summer), and (4) year of carcass recovery (1998, 1999, 2000, 2001). In 1997, carcasses were sampled only in November and December $(\mathrm{n}=6)$, and were therefore not included in among-year analyses. A non-parametric Kruskal-Wallis test was employed after log transformation of data failed to correct deviations from assumptions of normality and homoscedasticity. A non-parametric multiple comparison test (Q-test, Zar 1996) was used to determine which levels of a factor differed if the null hypothesis was rejected.

Rate of mortality due to infection by Profilicollis spp. was compared among age and sex category, carcass recovery area, season and year of carcass recovery using a chi-square test (Zar 1996). Expected frequencies were calculated by multiplying the total percent mortality for all sampled carcasses $(13.0 \%)$ by the sample size for each factor level. The null hypothesis in all chi-square tests was that 'observed frequency of mortality was equal among levels of a factor.'

\section{RESULTS}

\section{Acanthocephalans}

Two genera and 4 species of acanthocephalans (Corynosoma enhydri, Profilicollis altmani, $P$. kenti, and $P$. major) were found in our sample of sea otter carcasses from central California. Intensity of infection ranged from 1 to 6063 for C. enhydri, and 1 to 8760 for Profilicollis spp.
Profilicollis spp. were found in 75 of 162 (46.3\%) carcasses sampled. Within a sub-sample of 49 infected carcasses, $56 \%$ of identified profilicollids were $P$. altmani, $34 \%$ were $P$. kenti, and $10 \%$ were $P$. major. The overall mortality rate due to infection by Profilicollis spp. was $13.0 \%(n=21)$. Acanthocephalan peritonitis was either the primary or secondary cause of death in 16 cases, while intestinal acanthocephaladiosis contributed to mortality in 5 cases. Most carcasses with either acanthocephalan peritonitis or intestinal acanthocephaladiosis were also emaciated. Acanthocephalan peritonitis occurred in 14 of 16 (87.5\%) carcasses in which intensity of infection by $P$. altmani and $P$. kenti was greater than 350, but did not occur in carcasses infected only by P. major (Fig. 2). Intestinal perforation was noted in only 1 carcass with fewer than 350 parasites.

Among sampled carcasses, mean density of infection was significantly greater among juvenile and old-adult females than adult females $\left(Q_{\text {juvenile vs adult }}=\right.$ 3.53, $\mathrm{p}=0.02 ; Q_{\text {old-adult vs adult }}=3.42, \mathrm{p}=0.03$, Fig. 3A). Differences in mean density among other age/sex categories were not significant. Rate of mortality due to infection by Profilicollis spp. was significantly greater than expected among sub-adult males $(36.4 \%, \mathrm{n}=11)$ and old-adult females $(37.5 \%$, $\mathrm{n}=8$ ), and significantly less than expected among adult females $\left(2.5 \%, \mathrm{n}=40 ; \chi^{2}=17.479\right.$, df $=9$, $\mathrm{p}=$ 0.03).

Spatial patterns in mean density of Profilicollis spp. and percent mortality were similar. Within our sample, mean density of Profilicollis spp. was significantly

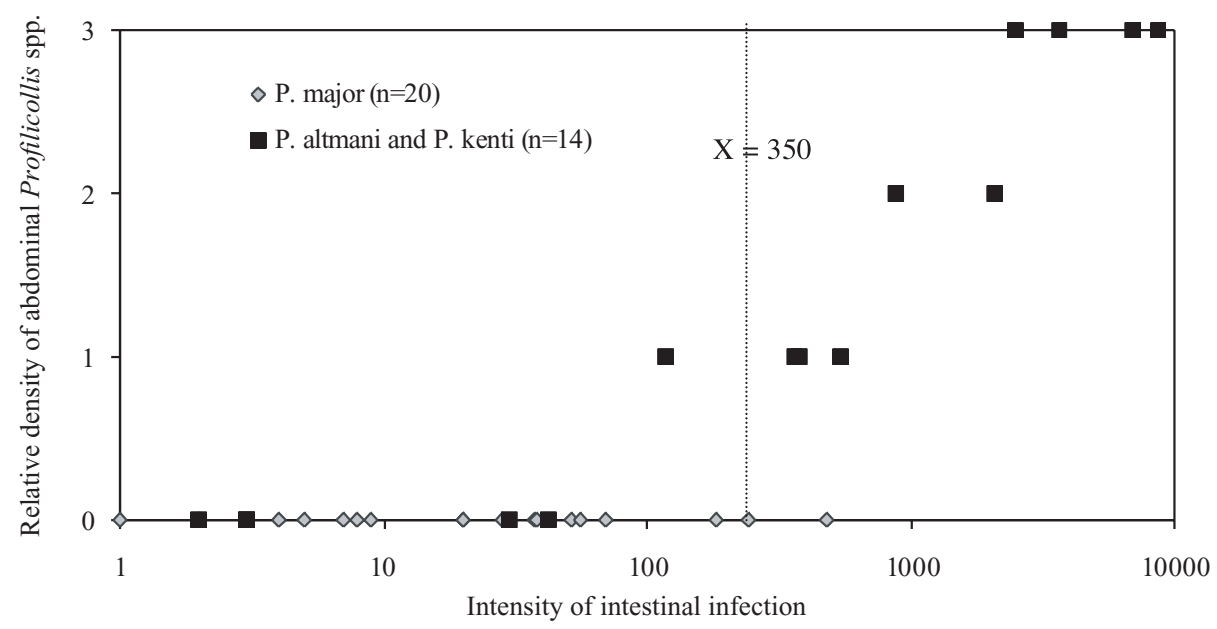

Fig. 2. Enhydra lutris nereis. Data from a sub-sample of carcasses infected by Profilicollis altmani and/or P. kenti (n = 14), or only by $P$. major $(\mathrm{n}=20)$. $P$. altmani and $P$. kenti were considered together because they appear to share intermediate hosts $(E m e r i t a$ analoga and Blepharipoda occidentalis), whereas P. major is transmitted to the sea otter via another, unidentified species of crab. Carcasses simultaneously infected by $P$. altmani, $P$. kenti and $P$. major were not considered $(\mathrm{n}=15)$. Relative density $(0=$ none, $1=$ light, 2 = moderate, 3 = heavy) of abdominal parasites was used for a qualitative estimate of the severity of intestinal perforation. A threshold intensity of infection may exist around 350 parasites: intestinal perforation occurred in 9 of 10 carcasses with $>350$ parasites, and in 1 of 24 carcasses with $<350$ parasites. Intestinal perforation did not occur in carcasses infected only by $P$. major 


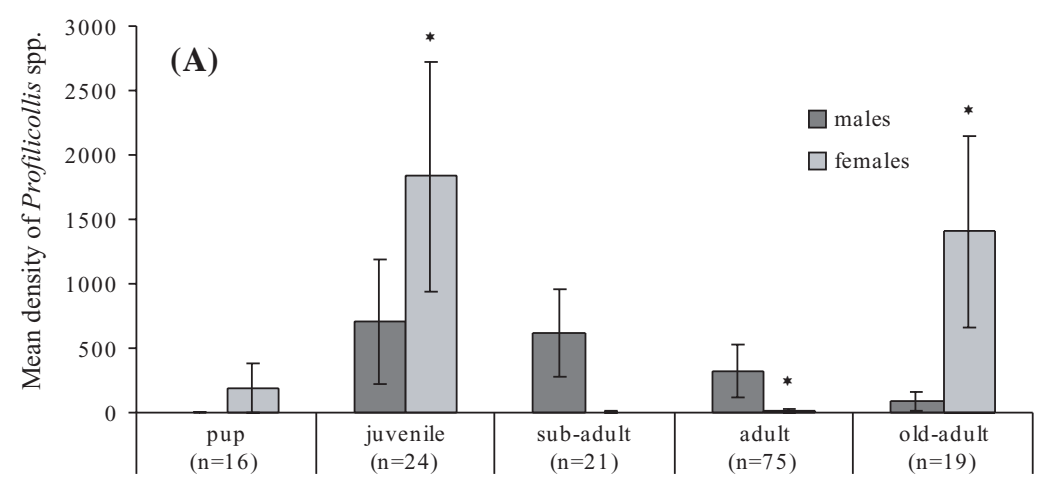

Fig. 3. Enhydra lutris nereis. Mean density of (A) Profilicollis spp. and (B) Corynosoma enhydri by sea otter age and sex category. Asterisks $\left({ }^{*}\right)$ indicate significant differences among age/sex categories. Prevalence of Profilicollis spp. infection within each age category was as follows: pups (19\%), juveniles $(54 \%)$, sub-adults (38\%), adults $(48 \%)$, and old-adults (53\%). Within each age category, prevalence did not differ between males and females, except among subadults, where $64 \%$ of males and $10 \%$ of females were infected. Prevalence of infection by $C$. enhydri was $100 \%$ for all age categories except pups $(50 \%)$. Sample sizes in each age category are indicated in parentheses. Error bars denote $\pm 1 \mathrm{SE}$ of the mean



greater in sea otter carcasses from sand habitat than from rock habitat $\left(Q_{\text {sand vs rock }}=3.42, \mathrm{p}=0.002\right.$, Fig. $\left.4 \mathrm{~A}\right)$. Mean density in mixed habitat was greater than in rock and less than in sand, but differences were not significant $\left(Q_{\text {mixed vs rock }}=2.19, \mathrm{p}=0.09\right)$. Acanthocephalan peritonitis was found in only 1 of $40(2.5 \%)$ sampled carcasses from rock habitats.

A particularly high concentration of heavily infected carcasses (>350 parasites) was found in a $4.5 \mathrm{~km}$ stretch of coastline just north of Monterey Municipal Wharf in south Monterey Bay. In this area, 6 of 13 (46.1\%) sampled carcasses had profilicollid infections of greater than 800 parasites. The cause of death in 5 of 6 cases was acanthocephalan peritonitis, and in 1 case, intestinal acanthocephaladiosis. All 6 were juvenile or sub-adult sea otters recovered in 1998 or 1999.

Mortality due to acanthocephalan peritonitis or intestinal acanthocephaladiasis was also relatively high among sampled beach cast otters from mixed habitat between Pt. Piños and Pt. Lobos, just south of Monterey $(23 \%, \mathrm{n}=21)$, and from sand habitat between Soquel Pt. and Moss Landing in northern Monterey Bay $(20 \%, \mathrm{n}=25)$. Mortality due to Profilicollis spp. occurred less frequently among sampled beach cast otters from sand habitat in Morro Bay (Cayucos Pier to Hazard Canyon, $12 \%, \mathrm{n}=25$ ) despite a relatively high mean density (Fig. 4A). In this area, 3 of 25 car- casses with acanthocephalan peritonitis had particularly massive infections (2200 to 8760 parasites): 2 individuals were old-adult females, 1 was a juvenile female.

Mortality due to infection by Profilicollis spp. was not found in sampled beach cast otters from Pismo Beach and South coast sand habitats (Fig. 4A). Within these areas, Profilicollis spp. were found in $58 \%(\mathrm{n}=17)$ of sampled carcasses, and intensity of infection ranged from 1 to 483; however, 99\% of profilicollids were identified as the less-pathologic species, $P$. major. Conversely, $P$. altmani and $P$. kenti occurred in a higher proportion of infected carcasses than $P$. major (83 vs $51 \%, \mathrm{n}=29$ ) in a sub-sample of infected carcasses from Monterey and Santa Cruz in the northern part of the sea otter range (Fig. 5). The higher prevalence of $P$. altmani and $P$. kenti in the north coincided with higher rates of mortality observed in these recovery areas (Fig. 4A).

Among sampled carcasses, inter-annual differences in mean density of Profilicollis spp. were not significant $(H=5.116$, df $=3, \mathrm{p}=0.16)$. Mean density in 2001 $(\bar{x}=519, \mathrm{SE}=485, \mathrm{n}=18)$ was high due to a particularly massive infection (8760 parasites) in 1 carcass from Morro Bay (reflected by high SE associated with the mean value, Fig. 6). Rates of mortality were greater in 1998 and 1999 than in 2000 and 2001; however, differ- 

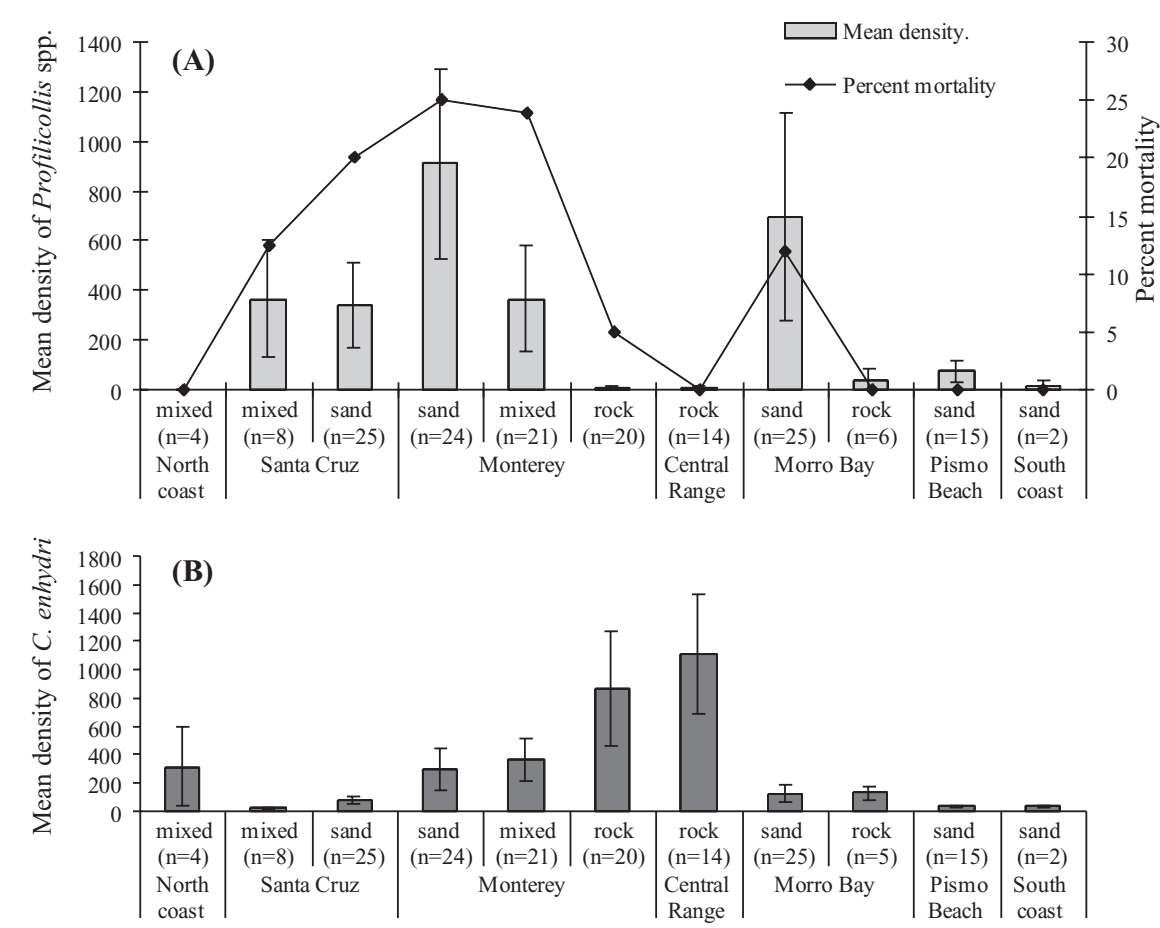

Carcass recovery areas
Fig. 4. Enhydra lutris nereis. Spatial variability in (A) mean density and \% mortality due to acanthocephalan peritonitis or intestinal acanthocephaladiosis and (B) mean density of Corynosoma enhydri in sampled sea otter carcasses. Individual sea otter carcass recovery sites were grouped into broader areas from north to south based on habitat-type (see Table 1). Mean density of Profilicollis spp. was significantly greater in carcasses from sand habitats than from rock habitats $\left(Q_{\text {sand vs rock }}=3.10, \mathrm{p}=\right.$ 0.005 ). Percent mortality due to infection by Profilicollis spp. was greatest in carcasses from sand and mixed habitats in the northern part of the sea otter range (Monterey and Santa Cruz); however differences among recovery areas were not significant $\left(\chi^{2}=11.856, \mathrm{df}=10\right.$, $\mathrm{p}=0.30$ ). Mean density of $C$. enhydri was significantly greater among carcasses from rock habitat than from sand $\left(Q_{\text {rock vs sand }}=3.240, \mathrm{p}=0.004\right)$ or mixed habitats $\left(Q_{\text {rock vs mixed }}=2.327, \mathrm{p}=0.06\right)$. Sample size within each recovery area is noted in parentheses. Error bars denote \pm 1 SE of the mean

\section{Digeneans}

ences were not significant $\left(\chi^{2}=3.983, \mathrm{df}=3, \mathrm{p}=0.40\right.$; Fig. 6). Mean density of Profilicollis spp. did not differ among seasons $(H=3.697, \mathrm{df}=3, \mathrm{p}=0.29)$.

Corynosoma enhydri was found in 153 of 162 (94.4\%) sea otters. Only pups were uninfected. Mean density of C. enhydri was significantly greater among sub-adult sea otters than among adult otters $(Q=3.61$, $k=5, \mathrm{p}<0.005)$ and pups $(Q=4.56, k=5, \mathrm{p}<0.001)$. Greatest mean densities were found among sub-adult males and females, and juvenile females (Fig. 3B).

Spatial patterns in mean density of Corynosoma enhydri were opposite to that of Profilicollis spp. Mean density was greater among carcasses from rock habitat than from sand $\left(Q_{\text {rock vs sand }}=3.240\right.$, $\mathrm{p}=0.004)$ or mixed habitats $\left(Q_{\text {rock vs }}\right.$ mixed $=2.327, \mathrm{p}=0.06$ ). Mean density of $C$. enhydri was greatest in carcasses recovered in Monterey and Central range rock habitats (Fig. 4B). Mean density of C. enhydri did not differ among seasons $(H$ $=4.591, \mathrm{df}=3, \mathrm{p}=0.20$ ) or among years $(H=6.751$, df $=3, \mathrm{p}=0.08)$.

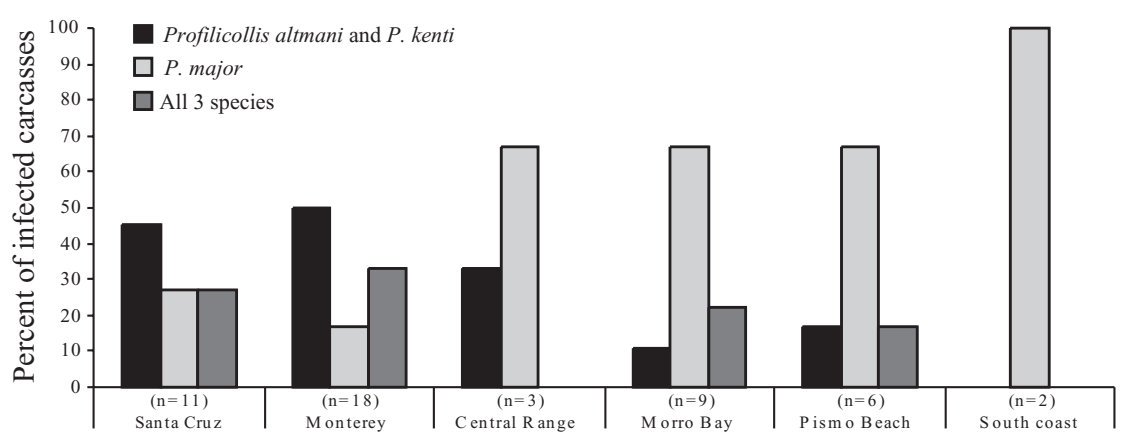

Carcass recovery area

Fig. 5. Enhydra lutris nereis. Spatial variability in the prevalence of Profilicollis altmani and $P$. kenti vs $P$. major from a sub-sample of 49 sea otter carcasses infected by Profilicollis spp. Due to low sample sizes, carcasses from different habitat types (sand, rock, mixed) within each recovery area were grouped together. $P$. altmani and $P$. kenti were considered together for 2 reasons: (1) both appear to share intermediate hosts, Emerita analoga and Blepharipoda occidentalis, and (2) both appear to be responsible for acanthocephalan peritonitis when present in large numbers. Conversely, $P$. major is transmitted to the sea otter through another, unidentified species of crab, and does not appear to be associated with intestinal perforation. P. altmani and $P$. kenti occurred in a higher proportion of infected carcasses than P. major (79\% vs $51 \%, \mathrm{n}=39$ ) from the northern part of the range (Monterey and Santa Cruz), whereas $P$. major occurred in a higher proportion of carcasses from the central and southern part of the range $(85 \%$ vs $30 \%, \mathrm{n}=20)$. Sample sizes within each area are shown in parentheses 


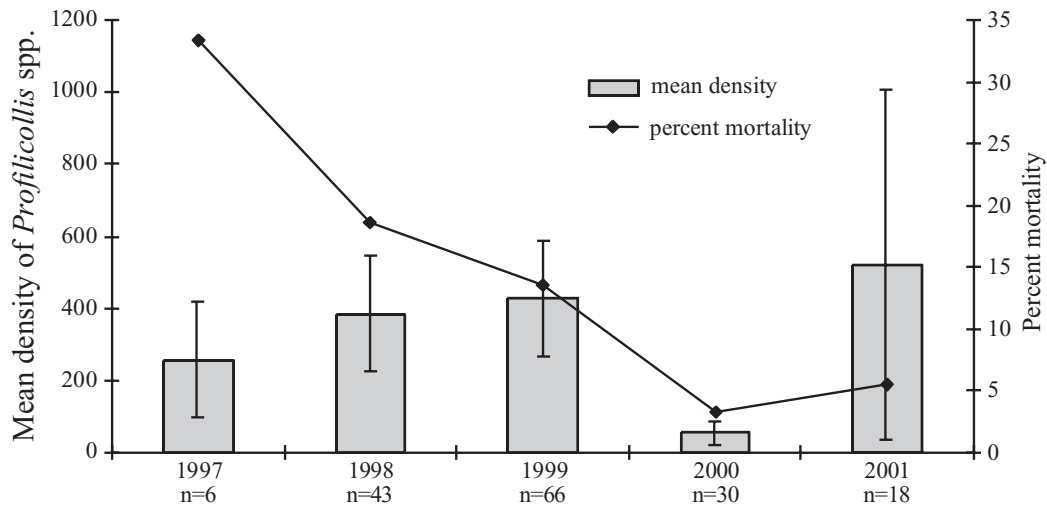

Fig. 6. Enhydra lutris nereis. Mean density of Profilicollis spp. and \% mortality due to acanthocephalan peritonitis or intestinal acanthocephaladiasis in sampled southern sea otter carcasses opportunistically collected between Pt. San Pedro and Pt. Arguello. Error bars denote $\pm 1 \mathrm{SE}$ of the mean. Differences in mean density $(H=5.116, \mathrm{df}=3, \mathrm{p}=0.163)$ and $\%$ mortality $\left(\chi^{2}=3.983, \mathrm{p}=0.40\right)$ among years were not significant. Number of sampled carcasses in each year is indicated below the $x$-axis. In 1997, carcasses were sampled only in November and December, and were therefore not included in among-year analyses. Mean density in 2001 was high relative to percent mortality due to a particularly massive infection (8760 parasites) in 1 carcass from Morro Bay (note high SE associated with this mean value)

and Plenosoma minimum Ching 1960) were found in the southern sea otter. This is the first report of the latter 2 species from the sea otter. Digeneans were identified in 41 of $87(47.1 \%)$ sampled carcasses. Mixed infections were found in extremely high densities $\left(>3000\right.$ per $\left.\mathrm{cm}^{2}\right)$ in the intestinal mucosa from the proximal duodenum through Meter 7 of the intestine. Eight of $12(66.7 \%)$ carcasses with heavy digenean infections were also heavily infected (>350 parasites) by Profilicollis spp. On histopathology, digeneans were observed on the mucosal surface, but were also observed within the intestinal mucosa, usually within the lumen of intestinal crypts.

\section{Histopathology of infection by Profilicollis spp.}

Numerous histopathological sections of acanthocephalan-infected otter intestine were examined. Minimal host inflammatory infiltrate was associated with Profillicollis spp. attached to the intestinal mucosa, including the villi and superficial lamina propria (Fig. 7A). Deeper penetration was associated with significant inflation of the parasite's anterior end (proboscis), accompanied by distortion and displacement of adjacent host tissues (Fig. 7B). The intramural portions of some acanthocephalans that had penetrated to the level of the submucosa and tunica muscularis were surrounded by a thin sheath of variably degenerate neutrophils. A prominent band of multinucleated giant cells and foreign body macrophages was often observed at the leading edge of the advancing parasite, forming an outer cap around the sheath of neutrophils (Fig. 7C). The outside edge of this cap of inflammatory cells was composed of moderate numbers of lymphocytes and plasma cells, and low numbers of plump, hyperplastic fibroblasts.

Profilicollids that had penetrated to the level of the outer intestinal wall were often associated with a thin cap of intact intestinal serosa as the only remaining barrier between the intestinal lumen, the transmural parasite and the abdomen (Fig. 8A). The parasite proboscis was often greatly enlarged and was surrounded by a large nodule of mixed inflammatory infiltrate (Fig. 8A). Adjacent host tissues were outwardly displaced by the inflated parasite proboscis and the host inflammatory infiltrate, forming the 1 to $2 \mathrm{~mm}^{3}$ raised, white nodules often observed grossly on the outer surface of sea otter intestines infected by Profilicollis spp.

Some profilicollids penetrated the intestinal serosa and entered the peritoneal cavity (Fig. 8B), sometimes accompanied by bacteria and fragments of digesta that were visible upon histopathologic examination. Grossly, Profilicollis spp. were found in all portions of the abdomen, pelvic canal and scrotum of affected otters, including the omentum, the surface of the diaphragm and the capsular surface of the liver, spleen and kidneys. The omentum was often mildly thickened grossly, with areas of patchy black pigmentation, and was moderately and diffusely expanded by lymphocytes, plasma cells, macrophages and neutrophils on histopathlogy. In affected animals, the mesothelium lining the peritoneal surfaces of the omentum and abdominal viscera was hyperplastic and cuboidal.

Host response to the free abdominal parasites was associated with grossly visible nodules of inflammatory infiltrate at points of parasite attachment. Upon histopathologic examination, these inflammatory nodules were composed of a small central core of degenerate neutrophils, surrounded by an outer rim of foreign body macrophages, multinucleated giant cells, lymphocytes and plasma cells, similar to that described for the outer intestinal wall. In more chronic cases, moderate numbers of plump, hyperplastic fibroblasts and developing scar tissue (fibroplasia) were associated with attached Profilicollis spp. parasites.

Grossly, many profilicollids on the outer intestinal surface and free within the abdomen appeared 


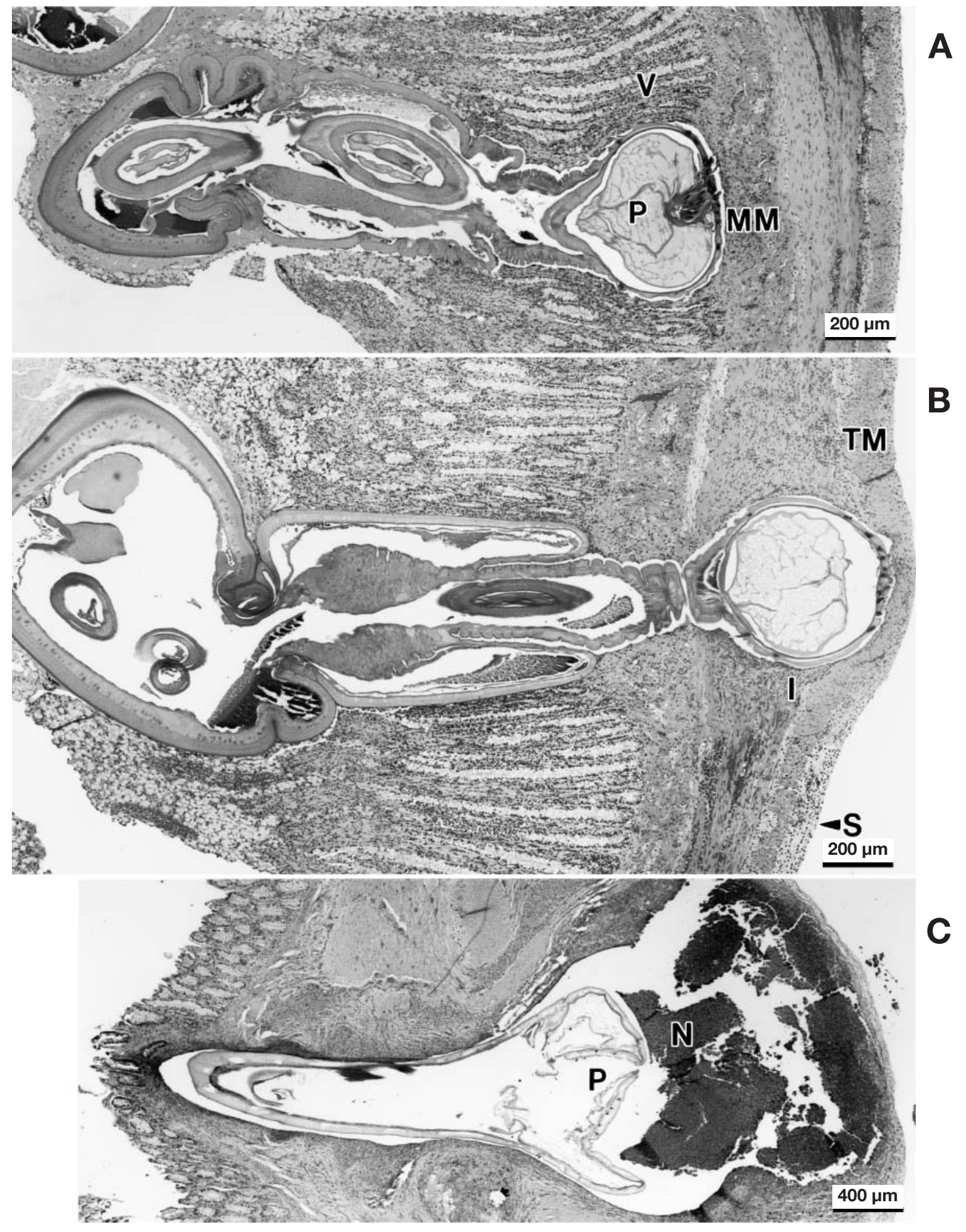

Fig. 7. Profilicollis sp. Multiple cross-sections of sea otter small intestine that extend from the intestinal lumen (left of figure) to the abdominal cavity (right of figure). (A) Profilicollis sp. has penetrated the intestinal mucosa to the level of the muscularis mucosa (MM). The intestinal villi (V) have been effaced or displaced laterally in the area of parasite penetration. Note the inflated proboscis (P) with prominent surface hooks, and the lack of a significant host inflammatory response. (B) Profilicollis sp. has penetrated to the external sheath of the tunica muscularis (TM). The proboscis is fully inflated. Some outward displacement of the external sheath of the tunica muscularis and serosa (S) is apparent. Mildly increasing numbers of inflammatory cells (I) are present in the surrounding tissue. (C) Intestinal perforation by Profilicollis sp. is imminent. Large numbers of degenerate neutrophils are present in a raised thin-walled inflammatory nodule $(\mathrm{N})$ located just below the serosal surface of the intestine. Surrounding the neutrophils is a prominent zone of reactive macrophages and multinucleated cells, interspersed with lymphocytes and plasma cells. The proboscis (P) has collapsed, perhaps artifactually 


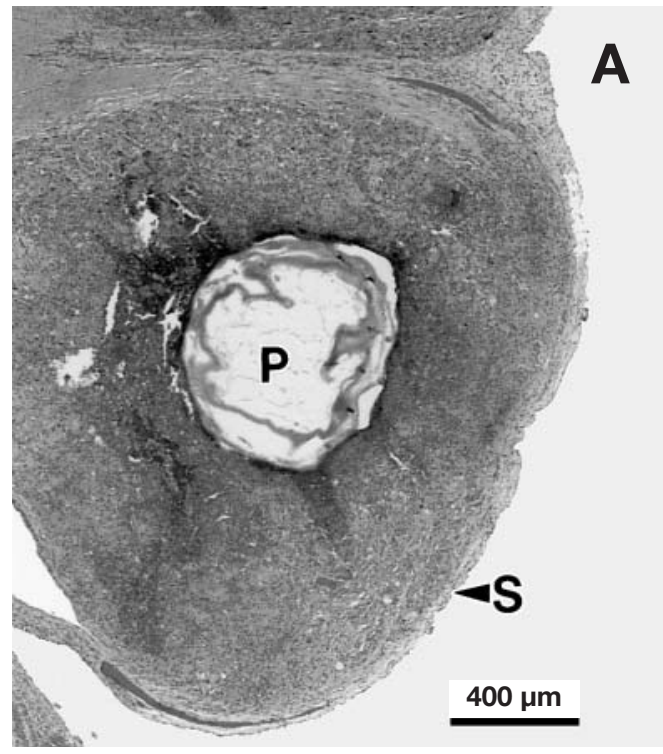

nonviable. This suggested that these acanthocephalans do not survive for long durations outside the host intestinal tract. Grossly, nonviable profilicollid acanthocephalans were firm to hard, white, and often had a bunched appearance. Upon histopathologic examination, nonviable acanthocephalans were characterized by loss of staining intensity and structural detail, as well as by mineralization of internal parasite structures (Fig. 8C). In addition, the internal portions of nonviable parasites were often infiltrated by host macrophages and neutrophils. In some sections, host inflammatory cell processing of the nonviable acanthocephalans was advanced, such that the only parasite structures that remained visible upon histopathologic examination were the hooks from the proboscis region, surrounded by foreign body macrophages, multinucleated giant cells and host scar tissue (Fig. 8C). At gross necropsy, some sea otters that had survived peritoneal invasion

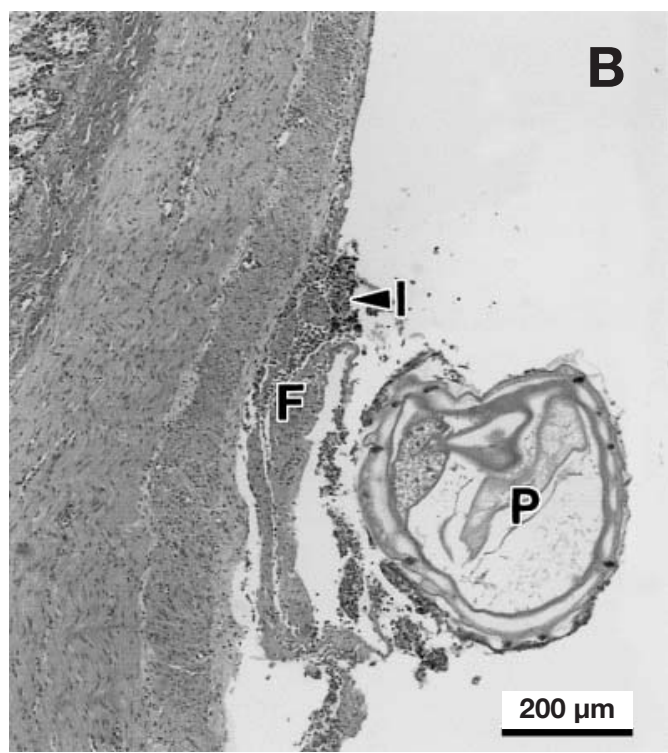

Fig. 8. Profilicollis sp. Perforation of the intestinal wall by Profilicollis sp. with reactive omentitis. (A) A well-developed subserosal inflammatory nodule from the small intestine of a sea otter, containing a prominent central Profilicollis sp. proboscis (P) that is fully inflated. The overlying intestinal serosa (S) has been outwardly displaced and attenuated by the expanding inflammatory nodule. (B) A Profilicollis sp. that has fully penetrated the intestinal wall. The inflated proboscis is outside the serosal surface, and is accompanied by fibrin $(\mathrm{F})$ and a mixed population of inflammatory cells (I). (C) Longitudinal section of Profilicollis sp. that has passed completely through the intestinal wall and died in the omentum. Indications that the parasite died prior to formalin fixation include discontinuities of the parasite body wall (D), loss of structural detail and mineralization of internal parasite structures (M). The surrounding omentum has been infiltrated by inflammatory cells

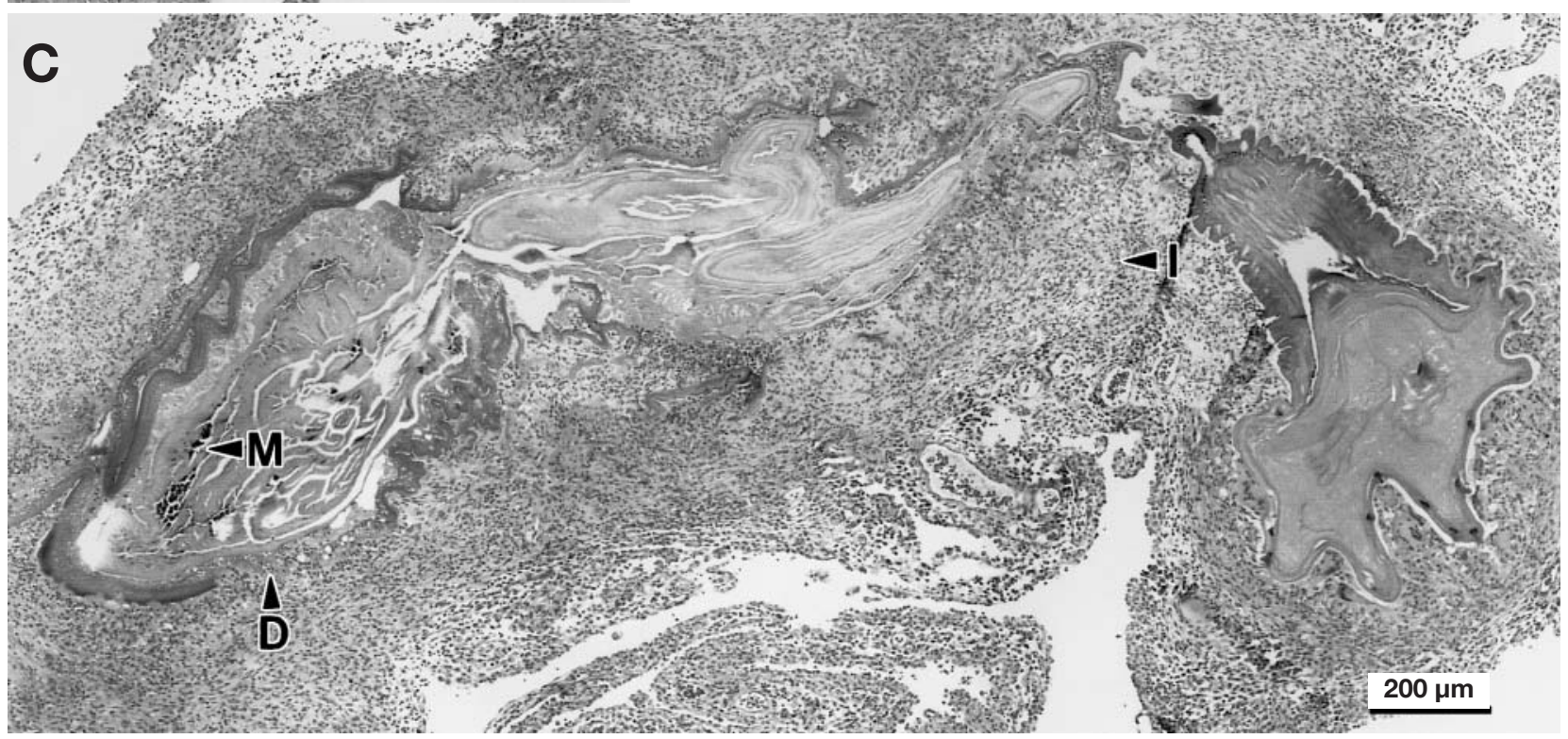


by acanthocephalans had multiple areas of omental adhesion and small mineralized serosal nodules, presumably points of scar (connective) tissue formation caused by degenerating acanthocephalan parasites.

In contrast, in all sections examined, points of intestinal attachment by Corynosoma enhydri were limited to the intestinal villi and superficial lamina propria and were not associated with significant host inflammatory response. In addition, significant inflation of the anterior portion of $C$. enhydri was not observed upon histopathologic examination. None of the intra- or extra-intestinal profilicollids examined appeared to be patent (egg-producing) while intra-intestinal $C$. enhydri were patent.

\section{DISCUSSION}

Data collected opportunistically from beach-cast carcasses represent a biased sample of mortality in the southern sea otter population. Potential sources of bias include: (1) Non-random disappearance of carcassesmortality occurring farther offshore, such as from shark attacks or entanglement in fishing gear-may be under-represented in beach-cast samples because these carcasses would be less likely to be deposited on shore; (2) Recovery bias-most carcasses are recovered from easily accessible areas adjacent to population centers, including Santa Cruz, Monterey, Morro Bay, and Pismo Beach. Conversely, very few carcasses are recovered from rocky habitat in the center of the sea otter range (between Yankee Pt. and Cayucos Pier), and causes of mortality affecting sea otters in this area are unknown; (3) Post-mortem drift/decomposition-carcasses may wash ashore shortly after death, or drift some distance prior to deposition depending on numerous environmental factors such as location, cause of death, wind and current direction, tidal state, waves, and physical characteristics of the coastline. Post-mortem drift potentially confounds spatial differences in mean parasite density and mortality rate.

In this study, we did not attempt to quantify the potential sources of bias listed above. As a result, conclusions related to spatial and temporal variability in density of Profilicollis spp. and Corynosoma enhydri and rate of mortality due to infection by Profilicollis spp. were limited to the sample population of carcasses, and not extrapolated more broadly to the southern sea otter population. Nevertheless, despite the limited scope of conclusions, certain factors associated with greater risk of infection and mortality emerged.

Among sampled sea otter carcasses, Profilicollis spp. were most abundant in juvenile and old-adult females. Thomas \& Cole (1996) reported most cases of acanthocephalan peritonitis in younger otters (pups and juve- niles). The occurrence of greater Profilicollis spp. infections among juvenile and old-adult females in our sample could be explained by several hypotheses, including food limitation in the southern sea otter population.

In a food-limited population, nutritional stress would disproportionately affect the poorest feeders (Ralls \& Siniff 1990). The poorest feeders may be at a competitive disadvantage relative to other age/sex groups, and therefore more susceptible to disease. In the southern sea otter, juvenile females spend a greater proportion of time feeding than juvenile males and adults (Ralls \& Siniff 1990) and have lower survival rates (Siniff \& Ralls 1991). No studies have documented nutritional stress on old-adult females in the southern sea otter; however, in a resource-limited population of northern sea otters (Amchitka Island), individual body condition was poorer among old-adult females ( $>12 \mathrm{yr}$ ) than younger adults (4 to $12 \mathrm{yr}$; Monson et al. 2000).

Alternatively, heavy parasite burdens in young and old females in our sample could be explained by increased parasite exposure through diet. Emerita analoga and Blepharipoda occidentalis are seasonally abundant along sandy beaches and would be relatively easy for sea otters to capture. These crustaceans, therefore, may be more heavily targeted by recently weaned juvenile sea otters just learning to feed independently, or by old females struggling to meet energy requirements with prey that is more difficult to capture. A combination of increased exposure to parasites and poor body condition may have contributed to high mortality due to Profilicollis spp. among juvenile and old-adult female sea otters in this study.

The adverse effects of infection by Profilicollis spp. also appeared to be concentrated geographically in sand and mixed-bottom habitats in Monterey and Santa Cruz in the north, and to a lesser extent, Morro Bay in the south. One hypothesis for observed spatial differences in mortality is that prevalence of intermediate hosts in sea otter diets varied among recovery areas. The relative distributions of $P$. altmani, $P$. kenti, and $P$. major appeared to support this hypothesis. Profilicollis altmani and P. kenti, transmitted to the sea otter through ingestion of sand crabs, were more prevalent than $P$. major among sampled carcasses from Monterey and Santa Cruz. Conversely, P. altmani and $P$. kenti rarely occurred in sampled carcasses from the south end of the range, where mortality due to acanthocephalan peritonitis was not found. In this area, otters may be less likely to forage on Emerita analoga and Blepharipoda occidentalis, and more likely to forage on Cancer spp. or other species of crabs or bivalves. Unfortunately, conclusions about spatial variability in feeding patterns of sea otters based on data from stranded carcasses were potentially confounded 
by the possibility of post-mortem drift. Alternatively, differential risk of infection based on area and habitat type could be a function of the density of parasites in intermediate hosts. Ongoing research is focused on whether density of Profilicollis spp. in intermediate hosts or prevalence of intermediate hosts in sea otter diets is correlated with observed spatial patterns of profilicollid density in sea otter carcasses.

Among sampled carcasses, mortality due to Profilicollis spp. decreased between 1998 and 2001. This trend is the opposite of the general increase in mortality identified by Thomas \& Cole (1996) in the early 1990s. These results suggest that sea otter mortality due to Profilicollis spp. may vary on multi-year cycles. The causes of this variability have not been investigated. One possibility is that greater prevalence of heavy profilicollid infections among southern sea otters (such as in 1998 and 1999) may coincide with greater densities of definitive hosts (particularly surf scoters Melanitta perspicillata) in Monterey Bay. Yearto-year changes in the density of surf scoters could ultimately have an impact on sea otter mortality through transmission of a greater number of $P$. altmani and $P$. kenti eggs to Emerita analoga and Blepharipoda occidentalis. The factors that determine the relative densities of surf scoters along the central California coast are unknown. Alternatively, exposure to parasites may vary temporally due to large-scale environmental perturbations (such as El Niño) that adversely affect the abundance and overall health of marine organisms at several trophic levels.

Of the 3 species of Digenea found in the southern sea otter during this study, only one, Microphallus pirum, has been previously reported (Margolis et al. 1997). Two species, Microphallus nicolli $(=$ Spelotrema nicolli) and Plenosoma minimum, were found in mixed infections with $M$. pirum at a maximum of 3750 per $\mathrm{cm}^{2}$. Heavy digenean infections tended to occur in carcasses that were also heavily infected by Profilicollis spp. When present in great numbers, digeneans may act to exacerbate the effects of profilicollids. Microphallus pirum was considered pathogenic, through mechanical damage, when found at 3000 per $\mathrm{cm}^{2}$ in Alaskan otters (Rausch 1953). Metacercaria of $M$. nicolli, which were infective to mice, have been previously reported in Emerita analoga collected from Santa Barbara, California (Ching 1965).

Based on results from gross necropsy and histopathological examination, sea otter mortality associated with heavy acanthocephalan burdens is multifactorial. First, high intra-intestinal acanthocephalan burdens are associated with significant melena, or digested blood. The exact mechanism of intestinal hemorrhage is unknown, but may be related to endoparasitism, and/or result from concurrent gastrointes- tinal erosions or ulceration. Chronic gastrointestinal bleeding leads to chronic intestinal protein and iron loss, and in severe cases, osmotic diarrhea. This extranutritional burden, along with potential interference with or competition for nutrient uptake by heavy burdens of acanthocephalans and digeneans, could be significant, especially for very young, very old, or sick otters.

As Profilicollis spp. reach high numbers and begin to penetrate the intestinal wall, an extra-nutritional burden could be further compounded by development of chronic inflammatory disease, requiring significant host energy-reserves to surround, kill, and phagocytize thousands of invading worms. The process of intestinal wall perforation by profilicollid acanthocephalan parasites appears to be due to parasite proboscis inflation and parasite migration through host tissues. In addition, degenerate neutrophils and intestinal bacteria distributed along the sides of the advancing parasite may contribute to the process of mural perforation through liquefactive necrosis of adjacent host tissues. These otters must also cope with digesta and opportunistic pathogens that gain access to the peritoneum through perforations in the intestinal wall. In some cases the immediate cause of death appears to be malnutrition due to depletion of energy reserves, while in others it is secondary septic peritonitis or systemic bacterial infection.

Although overall prevalence of Profilicollis spp. was high $(46.3 \%)$ in our sample of southern sea otters, acanthocephalan peritonitis and intestinal acanthocephaladiosis seemed to occur more frequently among juvenile and old-adult females, and in sea otters from sand and mixed habitats in the northern part of the range. Risk of infection by $P$. altmani and $P$. kenti may vary among years due to environmental factors such as changes in density of definitive hosts, or El Niño; however, further research is necessary to determine whether inter-annual differences in mortality are significant. Future research should endeavor to clarify the significance of variability in risk of infection to the southern sea otter population through comparative foraging studies, determination of density of Profilicollis spp. in intermediate hosts, and quantification of biases associated with use of carcass data.

Acknowledgements. We wish to thank Jack Ames, Mike Harris, Dave Jessup and the staff and volunteers of the Marine Wildlife Veterinary Care and Research Center in Santa Cruz, CA, for conducting sea otter necropsies, collecting samples, and offering the use of facilities and resources. Also our thanks to the California Department of Fish and Game, Santa Cruz, CA, Friends of the Sea Otter, Monterey, CA, and The Marine Mammal Center, Sausalito, CA, for financial support, and to Jim Harvey, Brian Hatfield, Nancy Thomas, Rebecca Cole, Viviana Wong, and Christine Kreuder for technical contributions. 


\section{LITERATURE CITED}

Amin OM (1992) Review of the genus Polymorphus Luhe, 1911 (Acanthocephala: Polymorphidae), with the synonymization of Hexaglandula Petrochenko, 1950, and Subcorynosoma Hoklova, 1967, and a key to the species. Qatar Univ Sci J 12:115-123

Ching HL (1965) Systematic notes on some North American microphallid trematodes. Proc Helminthol Soc Wash 32: 140-148

Dailey MD (1996) Essentials of Parasitology, 6th edn. WC Brown, Dubuque, IA

Hennessy SL, Morejohn VJ (1977) Acanthocephalan parasites of the sea otter, Enhydra lutris, off coastal California. Calif Fish Game 63:268-272

Hyman LH (1951) The pseudocoelomate Bilateria-Phylum Acanthocephala. Chapter XII. In: The invertebrates: Acanthocephala, Aschelminthes, and Entoprocta, Vol. III. McGraw-Hill, New York, p 1-52

Laidre KL, Jameson RJ, DeMaster DP (2001) An estimation of carrying capacity for sea otters along the California coast. Mar Mamm Sci 17(2):294-309

Margolis L, Groff JM, Johnson SC, McDonald TE, Kent ML, Blaylock RB (1997) Helminth parasites of sea otters (Enhydra lutris) from Prince William Sound, Alaska: comparisons with other populations of sea otters and comments on

Editorial responsibility: Otto Kinne (Managing Editor), Oldendorf, Germany the origin of their parasites. J Helminthol Soc Wash 64: 161-168

Monson DH, Estes JA, Bodkin JL, Siniff DB (2000) Life history plasticity and population regulation in sea otters. Oikos 90:457-468

Nickol BB, Crompton DWT, Searle DW (1999) Reintroduction of Profilicollis Meyer, 1931 as a genus in Acanthocephala: significance of the intermediate host. J Parasitol 85: 716-718

Ralls K, Siniff DB (1990) Time budgets and activity patterns in California sea otters. J Wildlife Man 54(2):251-259

Rausch R (1953) Studies on the helminth fauna of Alaska, XIII. Disease in the sea otter, with special reference to helminth parasites. Ecology 34:584-604

Rohde K (1982) Ecology of marine parasites. University of Queensland Press, St. Lucia

Schmidt GD, MacLean SA (1978) Polymorphus (Profilicollis) major Lundstrom 1942 juveniles in rock crabs, Cancer irroratus, from Maine. J Parasitol 64:953-954

Siniff DB, Ralls K (1991) Reproduction, survival and tag loss in California sea otters. Mar Mamm Sci 7(3):211-229

Thomas NJ, Cole RA (1996) The risk of disease and threats to the wild population. Endangered Species Update 13: $23-27$

Zar JH (1996) Biostatistical Analysis, 3rd edn. Prentice Hall, Upper Saddle River, NJ

Submitted: August 22, 2001; Accepted: June 12, 2002 Proofs received from author(s): January 14, 2002 